\title{
Tobacco Taxation in Croatia - Comparison Within EU Context
}

\author{
Željana Aljinović Barać, PhD \\ University of Split, Faculty of Economics Business and Tourism, Croatia \\ Ljerka Markota, PhD \\ RRiF plus d.o.o., Zagreb, Croatia \\ Andrijana Rogošić, PhD \\ Tina Vuko, PhD \\ University of Split, Faculty of Economics Business and Tourism, Croatia
}

Doi: 10.19044/esj.2018.c5p5

URL:http://dx.doi.org/10.19044/esj.2018.c5p5

\begin{abstract}
In order to instigate the smoking cessation various international initiatives highly recommend increased tobacco taxation as significant tool of tobacco control. This study examines tobacco taxation and its effects in Croatia comparing to the other EU Member States. The analysis is focused on taxation of cigarettes because the other tobacco products (like cigars, cigarillos, fine cut smoking tobacco) have low market share. The other reason for exclusion of the other tobacco product is lack of taxation harmonisation since Member States can choose between a specific duty or an ad valorem duty, or may apply a mixture of the two which prevents a valid comparability of taxation effects between EU countries. Research results show that there are great differences in amount of specific excise duty between EU countries. The other component of excise tax, ad valorem, varies between 1\% (in Denmark and Sweden) and 52\% of tax included retail selling price (in Finland). When total tax burden is considered, it was found that it varies from $69.39 \%$ of weighted average cigarettes price in Luxembourg to $89.57 \%$ in Estonia. The retail price of cigarettes in Croatia is among the lowest in EU despite the total tax burden of 81.1\%. Tobacco control activities in Croatia are showing progress but needing more effort in order to induce serious smoking cessation.
\end{abstract}

Keywords: Tobacco taxation, excise duty, MPOWER

\section{Introduction}

Smoking is one of the leading causes of illness and mortality so the governments from all around the world put much effort on breaking this bad 
habit among the citizens. In order to assist in country-level implementation of the WHO Framework Convention on Tobacco Control (WHO FCTC), WHO introduced in 2008 the 'MPOWER' package of six evidence-based tobacco control demand reduction measures:

- $\quad$ Monitor tobacco use and prevention policies

- Protect people from tobacco smoke

- Offer help to quit tobacco use

- Warn about the dangers of tobacco

- $\quad$ Enforce bans on tobacco advertising, promotion and sponsorship

- $\quad$ Raise taxes on tobacco.

MPOWER has been developed to help countries build their capacity to implement these provisions. The successful implementation of these measures will ultimately play a key role in reducing the cancer burden in these countries. The importance of demand reduction strategies as well as supply issues is asserted and thus WHO FCTC established a framework for an integrated multi-sectoral response to a grave public health issue (Mackay et al, 2012, p. 77). Raising taxes on tobacco products is one of the most costeffective measures to reduce cigarette consumption and, on the other hand, to increase domestic revenue which can be used for improving health and other programmes for the benefit of entire population. Tax policy is among the most common and relevant instruments in the toolkit of policy-makers when thinking about promoting growth (Canavire-Bacarreza, Martinez-Vazquez and Vulovic, 2013, p. 1). According to World Bank Group Tobacco Control Program assessments there are indications that higher tobacco tax rates could save millions of lives each decade, reduce poverty, and boost public resources for development investment. The World Bank Group Tobacco Control Program promotes introducing huge tobacco excise rate at once to attack affordability of tobacco products especially in low and middle income countries and among youth. Most of the countries have some form of tobacco taxation but the greatest effect is achieved with an excise tax since it applies exclusively to tobacco products and raises their prices making those products less affordable. The effectiveness of tax and price policies in the control of tobacco use and improvement of public health is studied and supported (Chaloupka, Straif and Leon, 2011). For tax policies to achieve the effect of reducing consumption, attention should be paid to the following (Zelenka, 2009, p. 468):

- the special tax should be increased so much that the price of tobacco products is raised above the average rate of inflation and increase in income, in order to ensure a constant reduction in the ability of people to afford tobacco products,

- prohibition of all customs and tax free sales of tobacco products, 
- redirecting a significant amount of government revenues, including those from tax on tobacco, into financing tobacco control programs,

- alignment of taxes and prices of all tobacco products to prevent exchange of one tobacco product for another.

Although the increased taxes are identified as single most effective tobacco control measure, the tax structure is what really matters. A crosscountry study (Shang et al., 2015) estimated how tax structures, including specific uniform, specific tiered, mixed uniform, mixed tiered, ad valorem uniform and ad valorem tiered structures, are associated with price variability measured by price ratios derived from the price distribution. The results show that complicated tax structures that depart from a specific uniform structure are associated with greater price variability. The findings (Shang et al., 2015, p. 5) suggest that switching to a simpler tax structure would significantly reduce price variability and thus reduce opportunities for tax avoidance. Specific uniform tax system is the most effective tax structure in reducing price variability and likely the most effective in reducing tobacco use and its consequences.

Besides mentioned, harmonisation of tax policies is required in order to mitigate certain types of illicit trade in tobacco products by reducing the incentives and opportunities to avoid and evade excise taxes. Blecher and Drope $(2015$, p. 7$)$ explained that a smoker has the opportunity to purchase cigarettes in a lower tax jurisdiction and consume them in a higher tax jurisdiction (tax avoidance, which is legal). Also, smuggling cigarettes is common when neighbouring countries do not have harmonised tax policies. Tax harmonisation thus reduces the incentives and opportunities for tax avoidance and evasion and EU is good example when tobacco products are being considered.

This paper examines the effects of tobacco taxation harmonisation (in Croatia) with EU regulations. Also, the estimation of tobacco control trends using MPOWER measurement and Tobacco Control Scale (developed by Joossens and Raw, 2006). The research objectives are threefold:

- to analyse the specific and ad valorem excise taxation in EU,

- $\quad$ to provide an insight in total tax burden (as percentage of weighted average price) of cigarettes in Croatia comparing to the other EU Member States,

- $\quad$ to assess the efforts made in Croatia to reduce tobacco consumption.

The paper is organized as follows. Next section presents regulation regarding tobacco control in Croatia. The third section gives an insight in tobacco taxation in Croatia comparing to the rest of EU countries as well as an assessment of tobacco control activities in Croatia. Concluding remarks are made in the final section. 


\section{Tobacco control policies in Croatia}

Croatia joined the EU on July, $1^{\text {st }} 2013$ so the taxation harmonisation process continued. In terms of tobacco products, EU members have among the highest cigarette taxes and prices in the world (Blecher and Drope, 2015, p. 9). The EU Directive 2011/64 defines the tobacco product categories, structure and minimum rates for excise duties on manufactured tobacco. EU excise duty rules broadly differentiate between cigarettes and other tobacco products. According to the mentioned EU Directive, excise duty on cigarettes must consist of two components:

- $\quad$ a specific component i.e. a fixed amount per 1000 cigarettes.

- $\quad$ an ad valorem component i.e. a percentage of the retail selling price

These two components must be the same for cigarettes of all price categories. The Directive prescribes the minimum rates which Member States must respect but they can set the greater rates as well. For the other tobacco products (cigars, cigarillos, fine cut smoking tobacco) Member States can choose between a specific duty or an ad valorem duty, or may apply a mixture of the two. Minimum rates for cigars, cigarillos and fine cut smoking tobacco are set out by the same Directive and Member States are free to apply national rates above theses minima.

Member States have to levy a minimum rate of excise duties on cigarettes and this minimum rate must consist of:

- A specific component of between $7.5 \%$ and $76.5 \%$ of the total tax burden (TTB) - expressed as a fixed amount per 1000 cigarettes

- An ad valorem component - expressed as a percentage of the maximum retail selling price

In addition, the overall excise rate must be:

- $\quad$ At least EUR 90 per 1000 cigarettes

- At least $60 \%$ of the weighted average retail selling price

It must be pointed out that EU Member State that applies excise duty of EUR 115 or more, however, does not need to comply with the $60 \%$ criterion mentioned above.

Taxation of tobacco products in Croatia is regulated by Excise Duty Act (Official Gazette, No. 22/13, 32/13, 81/13, 100/15, 120/15 and 115/16) and Ordinance on excise duties (Official Gazette No. 1/17 and 14/17). Those regulations mainly incorporate European excise institutes into the legislation of the Republic of Croatia and harmonise Croatian excise duties with the minimum amounts of excise rates prescribed in EU directives.

According to the Act, excisable products and amounts of excise duties on tobacco products in Croatia are: 
- $\quad$ Cigarettes - Specific excise: approx. €41 (310 HRK) /1,000 items + Ad valorem excise: $34 \%$ of retail selling price; Minimum excise approx. €93 (696 HRK)/1,000 pieces. $^{2}$

- Cigars and cigarillos - Specific excise: approx. €80 (600 HRK) /1,000 items

- $\quad$ Fine cut smoking tobacco and other smoking tobacco - Specific excise: approx. $€ 80$ (600 HRK) /1 kg of product

All tobacco products that have been taxed are marked with fiscal control stamps of the Ministry of Finance (MF). The printed stamps are kept in the main vault of the MF in the Central Office of the Tax Administration and are delivered to the auxiliary vaults of the producers or directly taken over by the taxpayers. The person who took over the stamps is excise taxpayer and is obliged to pay the calculated excise amount to customs within a period of 30 days.

Although it is not in compliance with EU acquis, the following tobacco products are subject to excise duties from the beginning of 2017 in Croatia:

- $\quad$ E-liquids - Specific excise: approx. €0 (0 HRK) /1 ml of product

- Heated tobacco products (e.g. IQOS-heat sticks, Ploom tobacco capsules) - Specific excise: approx. $€ 80$ (600 HRK) /1 kg of product

- $\quad$ New tobacco products (e.g. Hookah Squeeze steam paste, Ice Rockz steam stone, Ice Frutz Hookah gel) - Specific excise: approx. €80 (600 HRK) $/ 1 \mathrm{~kg}$ of product.

Besides taxation, Croatian legislation gives framework for protection of population from the harmful effects of tobacco smoke. Smoking at work is forbidden by the Occupational Health and Safety Act. However, companies and organizations have the right to establish through internal acts in which rooms smoking is permitted, taking into account the right of non-smokers not to be exposed to tobacco smoke from their environment, as well as the danger of smoking in certain work processes (danger of fire etc). The Act on Health Quality and Health Inspection of Food and Items for General Consumption prohibits direct advertising of tobacco and tobacco products and regulated the quantity of tax and nicotine in cigarettes (Zelenka, 2009, p. 467). From the end of 1999 the use of tobacco products has been primarily regulated by the Act on the Limitation of Use of Tobacco Products (OG 128/99, 137/04, 125/08). This Act prescribes precise health warnings on tobacco product packages. Direct and indirect advertising of tobacco

\footnotetext{
${ }^{2}$ Note: In the calculation of the specific excise, a cigarette is deemed to be a role of tobacco the length of which exclusive of tip or filter is up to $8 \mathrm{~cm}$, two cigarettes will be deemed to be constituted by cigarettes from 8 to $11 \mathrm{~cm}$, and three from 11 to $14 \mathrm{~cm}$, i.e. every additional $3 \mathrm{~cm}$ of length of a roll of tobacco without a filter will represent an increase of one cigarette.
} 
products is forbidden in Croatia. Also, it is forbidden to sponsor events, activities or individuals with the purpose, effect or potential effect of direct or indirect advertising of tobacco products or the use of tobacco.

\section{Research methodology and results}

The study is focused on taxation of cigarettes due to their prevailing market share comparing to the other tobacco products (Figure 1 and 2). Bearing in mind that the EU Directive 2011/64 clearly prescribes the tax structure and a minimum rate of excise duties on cigarettes we based this study on five research questions:

RQ1: Are there the differences in specific excise duties on cigarettes between EU Member States?

RQ2: Which EU countries have the greatest ad valorem excise duty component?

RQ3: How great is the tax burden on cigarettes in Croatia comparing to the other EU Member States?

RQ4: What are the weighted average prices (WAP) for cigarettes across EU in the context of possibility of excise duty increase in Croatia?

RQ5: What are the trends of tobacco control in Croatia?

The secondary analysis of existing data is employed as the main research methodology. Publically available tobacco related data was selected from Euromonitor International and World Bank databases and retrieved from European Commission - Taxation and Customs Unit (Indirect Taxation and Tax administration). Data was used for the analysis performed in SPSS and MS Excel.

As illustrated in Figure 1, cigarettes are the most consumed type of tobacco products in the entire world and even more in Croatia where the market share of cigarettes is $96 \%$ (Figure 2) according to the data Euromonitor International on tobacco retail volume in 2016. 
Figure 1: World market share of tobacco products

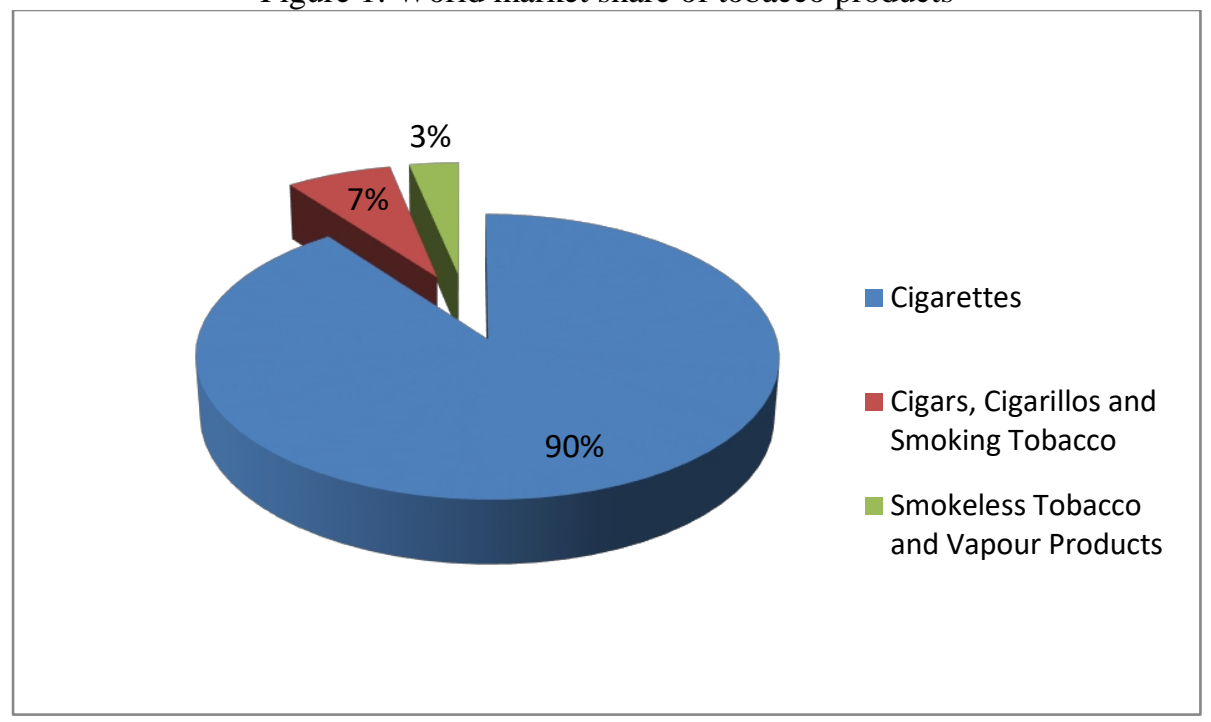

Source: Data complied from Euromonitor International (2018)

Figure 2: Market share of tobacco products in Croatia

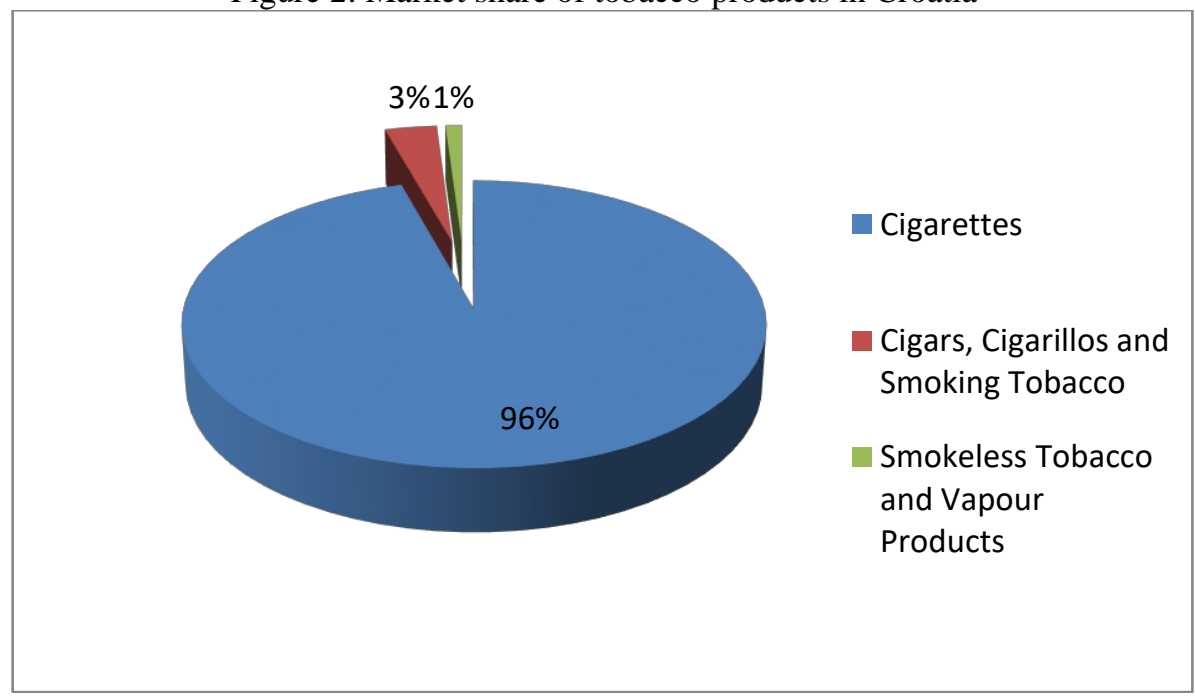

Source: Data complied from Euromonitor International (2018)

As stated earlier, excise duty on cigarettes in EU consists of two components: specific (fixed amount per 1000 cigarettes) and ad valorem (percentage of tax included retail selling price). According to the most recent European Commission data (for the year 2017), the lowest amount of specific excise duty on cigarettes is in Luxembourg (18.89 EUR) followed by Italy (19.28 EUR) while the highest amount is recorded in Ireland (309.04 EUR). As shown in Table 1, mean value of specific excise (per 1000 cigarettes) in EU is 86.16 EUR while the median is 63.20 EUR. The specific 
excise duty on cigarettes in Croatia is 41.35 EUR which makes it bellow the EU average. Since the standard deviation is 66.61 EUR (per 1000 cigarettes) it can be stated that the differences among Member States in the value of specific excise are huge.

Table 1: Descriptive statistics - specific excise duty

\begin{tabular}{|c|c|}
\hline \multicolumn{1}{|c|}{ Valid } & 28 \\
Missing & 0 \\
Mean & 86,1605 \\
Median & 63,1996 \\
Std. Deviation & 66,61123 \\
Variance & 4437,056 \\
Minimum & 18,89 \\
Maximum & 309,04 \\
\hline
\end{tabular}

Source: Authors' calculation according Excise Duty Tables - European Commission (2018)

Figure 3: Specific excise duty per 1000 cigarettes in EU

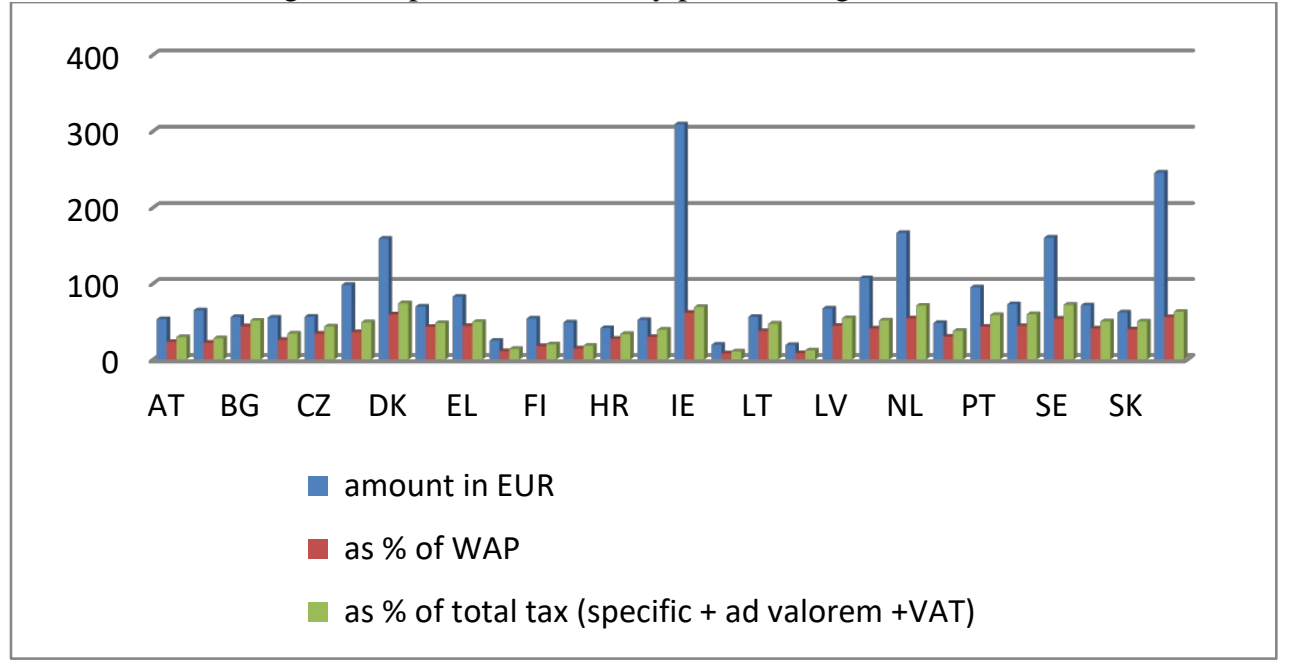

Source: Data retrieved from Excise Duty Tables - European Commission (2018)

Italy has the lowest percentage of specific excise in weighted average cigarettes price which is $8.1 \%$ while the greatest share is recorded in Ireland $(61.38 \%)$ followed by Denmark $(59.28 \%$ of WAP). The registered specific excise as percentage of weighted average cigarettes price in Croatia is $27.1 \%$. Absolute and relative specific excise duty on cigarettes considerably varies between EU countries as illustrated in Figure 3.

Ad valorem excise duty on cigarettes in each EU country is shown in Figure 4. The lowest percentage of ad valorem excise in tax included retail selling price (TIRSP) is in Denmark and Sweden (only 1\%) while in Finland this duty is $52 \%$ followed by Italy and Spain where ad valorem excise is $51 \%$ 
of TIRSP. Croatia recorded $34 \%$ of ad valorem excise on cigarettes in tax included retail selling price. Since standard rate of value added tax (VAT) in EU varies from $17 \%$ in Luxembourg to $27 \%$ in Hungary, the tax burden that derives from it is reflected on total tax on cigarettes (Figure 5).

Figure 4: Ad valorem excise duty in EU Member States

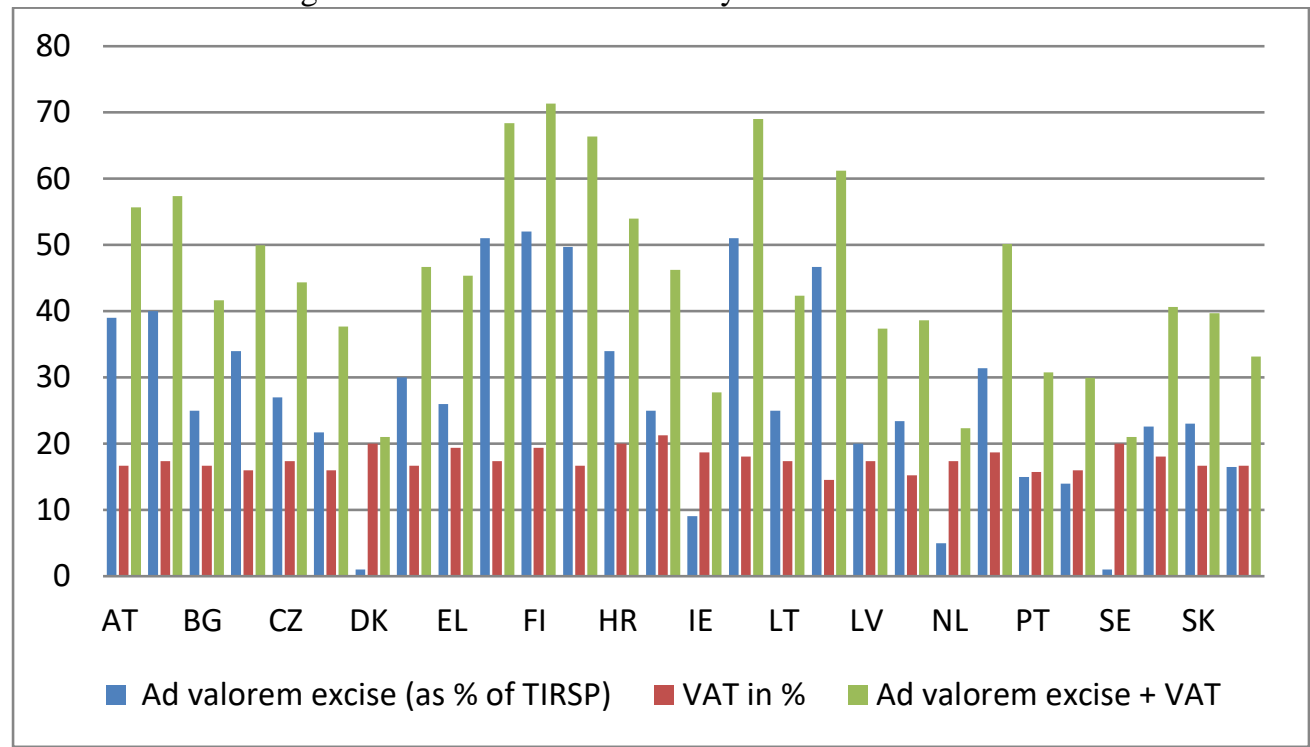

Source: Data retrieved from Excise Duty Tables - European Commission (2018)

Total tax burden on cigarettes as a percentage of WAP varies from 69.39\% in Luxembourg to $89.57 \%$ in Estonia (Table 2 and Figure 5). The mean value of total tax burden in EU is $80.03 \%$ and the median is $79,39 \%$ of WAP (Table 2) which puts Croatia (with 81.1\%) among the high taxation countries when tobacco products are considered.

Table 2: Descriptive statistics - total tax burden on cigarettes

\begin{tabular}{|c|c|}
\hline Valid & 28 \\
Missing & 0 \\
Mean & 80,0275 \\
Median & 79,3850 \\
Std. Deviation & 5,36707 \\
Variance & 28,805 \\
Minimum & 69,39 \\
Maximum & 89,57 \\
\hline
\end{tabular}

Source: Authors' calculation according Excise Duty Tables - European Commission (2018)

Figure 5: Total tax burden as a percentage of weighted average cigarettes price 


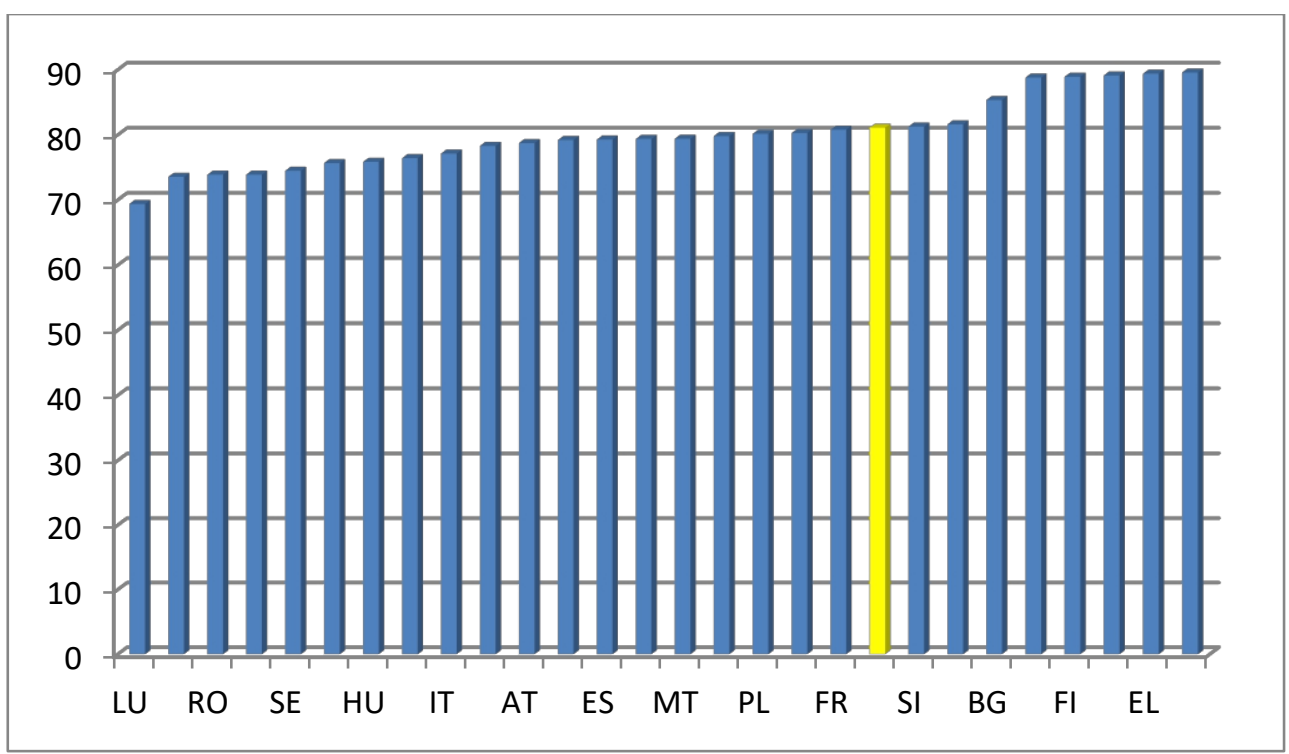

Source: Data retrieved from Excise Duty Tables - European Commission (2018)

On the other hand, total tax burden, opposite to the expectations, does not significantly affect the retail price of cigarettes in EU as shown in Table 3.

Table 3: Correlation between total tax burden (as percentage of WAP) and WAP

\begin{tabular}{|cc|c|c|}
\hline & & Total tax burden & WAP \\
\hline $\begin{array}{c}\text { Total tax } \\
\text { burden }\end{array}$ & Pearson Correlation & 1 & 0,242 \\
& Sig. (2-tailed) & & 0,214 \\
& $\mathrm{~N}$ & 28 & 28 \\
\hline WAP & Pearson Correlation & 0,242 & 1 \\
& Sig. (2-tailed) & 0,214 & \\
& $\mathrm{~N}$ & 28 & 28 \\
\hline
\end{tabular}

Source: Authors' calculation according Excise Duty Tables - European Commission (2018)

Although EU strengthened the tax requirements for Member States in 2010 and consequently reduced variation in cigarette prices was expected (Blecher, Ross and Stoklosa, 2014), weighted average price per 1000 cigarettes in 2017 is in range from 127.57 EUR in Bulgaria to 503.50 EUR in Ireland (Figure 6). Croatia is among those EU countries with affordable prices of cigarettes though total tax burden is relatively high. According to the results presented in Figure 6, Croatia can increase excise duty on tobacco products but the question remains if it will significantly affect the retail price making cigarettes and other tobacco products less affordable (which leads to smoking cessation). 
Figure 6: Weighted average price per 1000 cigarettes in EU

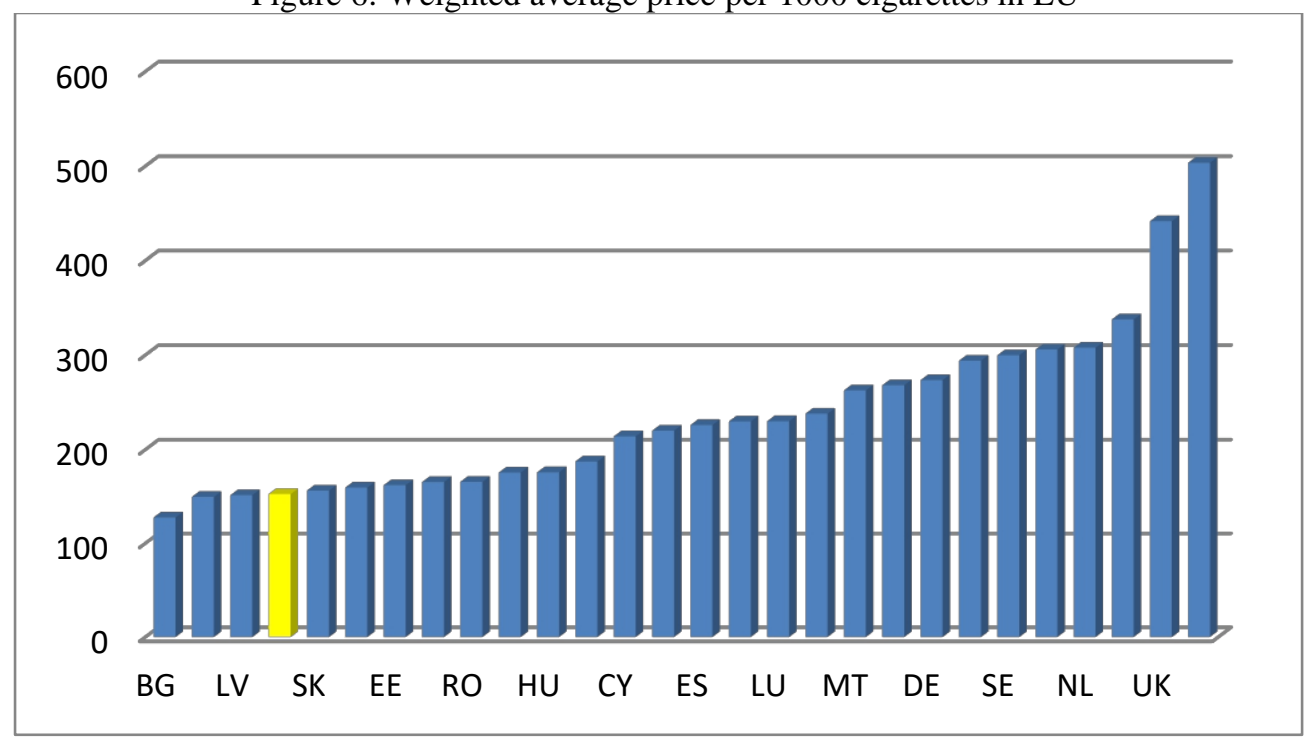

Source: Data retrieved from Excise Duty Tables - European Commission (2018)

The cigarette consumption in Croatia is slowly decreasing and according to Euromonitor forecast by the year 2021 that trend is continuing as illustrated in Figure 7.

Figure 7: Trends of cigarette consumption in Croatia

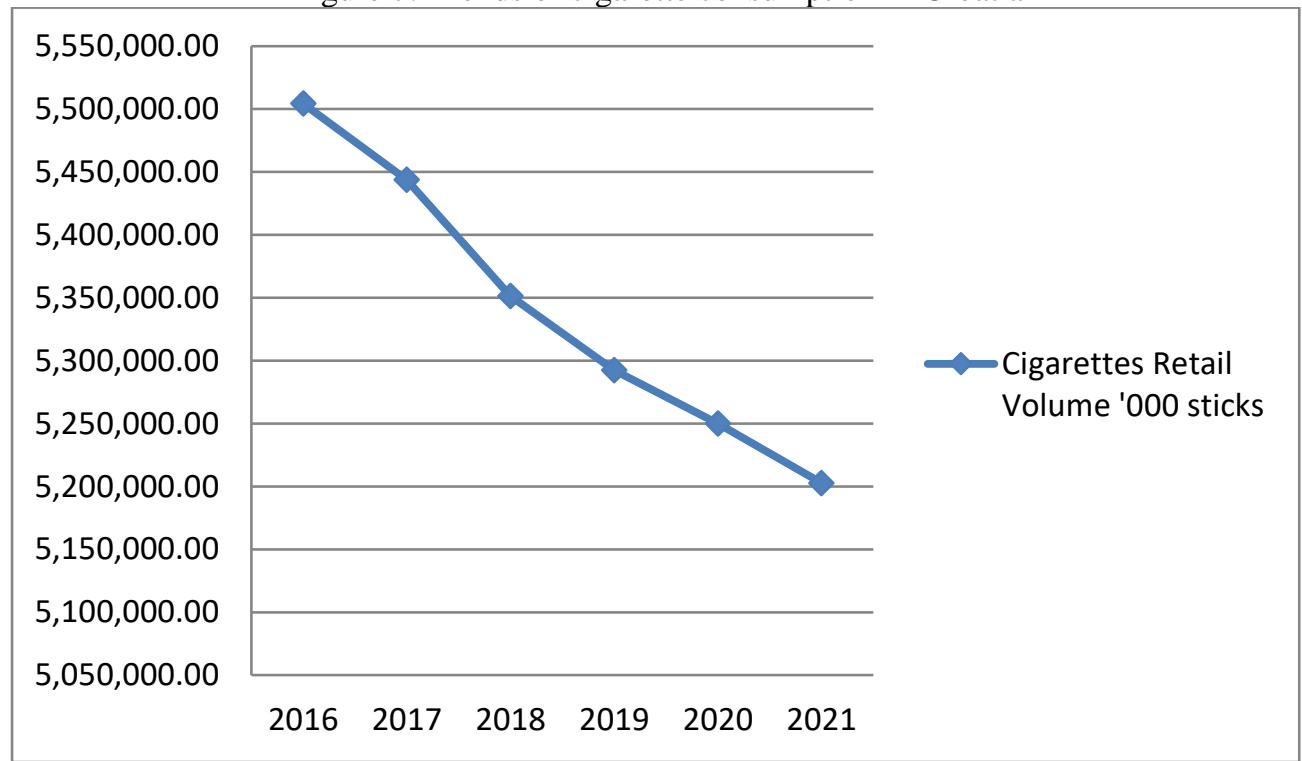

Source: Data retrieved from Euromonitor International (2018)

Tobacco control efforts made in Croatia to reduce smoking can be assessed in various ways. For the purpose of this study, two well framed international measures which quantify the implementation of tobacco control 
policies at country level: MPOWER and Tobacco Control Scale (TCS) are used. The most recent available data of MPOWER and TCS are for the year 2016. According to MPOWER report, Croatia has exceled in monitoring (by providing representative and periodic data on tobacco consumption of adults and youth) and in taxation (since more of $75 \%$ of retail price is tax). Much effort is made for treatment of tobacco dependence (cessation programmes) and enforcing bans on tobacco advertising, promotion and sponsorship but Croatia has to do more regarding policies on smoke-free environments, health warnings on tobacco packages, organizing national anti-tobacco campaigns. Summary of Croatian achievement according MPOWER requirements is graphically illustrated in Figure 8.

Figure 8: Summary of MPOWER measures for Croatia

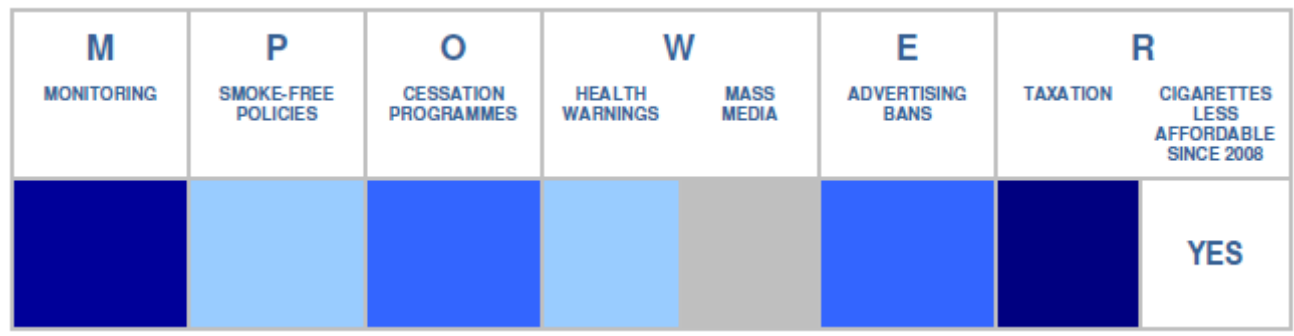

Source: World Health Organization Report on the Global Tobacco Epidemic (2017)

The TCS is based on six policies described by the World Bank:

- $\quad$ Price increases through higher taxes on cigarettes and other tobacco products;

- Bans/restrictions on smoking in public and work places;

- Better consumer information, including public information campaigns, media coverage, and publicising research findings;

- $\quad$ Comprehensive bans on the advertising and promotion of all tobacco products, logos and brand names;

- Large, direct health warning labels on cigarette boxes and other tobacco products;

- Treatment to help dependent smokers stop, including increased access to medications.

When first introduced in the TCS report (for the year 2013), Croatia gained TCS score of 40 and in 2016 that score was 45 so the progress was detected. According to the TCS report in 2016, first ranked was United Kingdom with score of 81 (maximum is 100 points). Among 35 European countries that were assessed, Croatia was ranked $23^{\text {rd }}$ (Joossens and Raw, 2016). The analysis shows that tobacco control spending per capita by the government, expressed in Power Purchasing Standards, is quite low in Croatia (scoring 1of 15). Large direct health warnings are also low rated (scoring 1 of 10). According to this methodology of assessing tobacco 
control activities, Croatia is best rated when comprehensive bans on tobacco advertising and promotion are concerned (scoring 12 of 13). The weighted average price for cigarettes, taking into account Purchasing Power Standards, gained 16 out of 30 points. Croatia has much to do regarding treatment to help smokers to stop smoking (scored 4 out 10 points). Also, smoke-free public places, especially bars and restaurants as well as work place need to be more regulated in order to comply with the European Council Recommendation of 30 November 2009 on Smoke-free Environments (2009/C 296/02). To sum up, tobacco control activities are in progress and Croatia should be able to improve its tobacco control score in the coming years (Joossens and Raw, 2017, p. 12).

Although those two measurement systems of tobacco control at country level share the same framework and ultimate goal, the methodology is different so the mentioned results for Croatia seem conflicting (at least on surface) at some points. Good example of the mentioned dissimilarity is treatment of tobacco dependence which is assessed in the TCS by: recording of smoking status in medical notes, legal or financial incentive to record smoking status in all medical notes or patient files, brief advice in primary care, family doctors reimbursed for providing brief advice, quitline and national quitline (or quitlines in all major regions of country). On the other hand, MPOWER methodology is based more on availability of nicotine replacement therapy, accessibility of Bupropion and Varenicline and smoking cessation support.

\section{Conclusion}

Although tobacco control relies on several factors, taxation forms significant part of an overall strategy of prevention and dissuasion of tobacco consumption. Taxation of cigarettes in EU is harmonised but Member States can decide whether to apply a specific duty on the other tobacco products or an ad valorem duty, or may prescribe a mixture of the two. Harmonised taxation did not result in similar retail prices of cigarettes in EU. The weighted average price per 1000 cigarettes in 2017 is in range from 127.57 EUR (in Bulgaria) to 503.50 EUR (in Ireland). Croatia has high level of total tax burden ( $81.1 \%$ of weighted average cigarettes price) but the retail price remained among the lowest in EU. If Croatia introduces larger amount of specific excise maybe it would make cigarettes less affordable for Croatian citizens and encourage them to stop smoking. According to the MPOWER and TSC reports, Croatia is making progress but still has much to do in order to achieve better results in smoking cessation and tobacco consumption prevention. 


\section{References:}

1. Act on the Limitation of Use of Tobacco Products, Official Gazette (No. 128/99, 137/04, 125/08)

2. Blecher Evan, Drope Jeffrey (2014): The rewards, risks and challenges of regional tobacco tax harmonisation, Tobacco Control, Vol. 23, pp. 7-11.

3. Blecher Evan, Ross Hana, Stoklosa Michal (2014): Lessons learned from cigarette tax harmonisation in the European Union, Tobacco Control, Vol. 23 (e1), pp. 12-14

4. Canavire-Bacarreza Gustavo, Martinez-Vazquez Jorge and Vulovic Violeta (2013): Taxation and economic growth in Latin America, Inter-American Development Bank http: http://www20.iadb.org/intal/catalogo/PE/2013/12729.pdf (accessed: 11/04/2018)

5. Chaloupka Frank J, Straif Kurt and Leon Maria E (2011): Effectiveness of tax and price policies in tobacco control, Tobacco Control, Vol. 20, pp.235-238.

6. Euromonitor International, http://www.euromonitor.com/ (accessed: 11/04/2018)

7. European Commission (2018): Excise Duty Tables (Part IIIManufactured

https:/ec.europa.eu/taxation_customs/sites/taxation/files/resources/do cuments/taxation/excise_duties/tobacco_products/rates/excise_dutiespart_iii_tobacco_en.pdf (accessed: 6/04/2018)

8. European Council Directive 2011/64/EU of 21 June 2011 on the structure and rates of excise duty applied to manufactured tobacco

9. Excise Duty Act, Official Gazette (No. 22/13, 32/13, 81/13, 100/15, 120/15 and 115/16)

10. Joossens Luk and Raw Martin (2006): The Tobacco Control Scale: a new scale to measure country activity, Tobacco Control, Vol. 15, No. 3, pp. 247-253.

11. Joossens Luk and Raw Martin (2017): The Tobacco Control Scale 2016 in Europe, Association of European Cancer Leagues, http://www.tobaccocontrolscale.org/wpcontent/uploads/2017/03/TCS-2016-in-Europe-COMPLETELoRes.pdf

12. (accessed: 10/04/2018)

13. Ordinance on excise duties, Official Gazette (No. 1/17 and 14/17)

14. Shang Ce, Chaloupka Frank J, Fong Geoffery T, Thompson Mary, O'Connor Richard J (2015): The association between tax structure and cigarette price variability: findings from the International 
Tobacco Control Policy Evaluation (ITC) Project, Tobacco Control, 24 (Suppl 3), pp. $1-6$

15. World Bank Group Tobacco Control Program, http://www.worldbank.org/en/topic/health/brief/tobacco (accessed: 2/04/2018)

16. World Health Organization Report on the Global Tobacco Epidemic (2017):

http://www.who.int/tobacco/surveillance/policy/country_profile/hrv.p df?ua=1 (accessed: 2/04/2018)

17. Zelenka Ida (2009): Tax Policy Impact on Consumption of Tobacco Products in Croatia, Financial Theory and Practice, Vol. 33, No. 4, pp. 465-479 